\title{
Diurnal Variation in Ruminal pH on the Digestibility of Highly Digestible Perennial Ryegrass During Continuous Culture Fermentation
}

\author{
W. J. Wales, ${ }^{1}$ E. S. Kolver, ${ }^{2}$ P. L. Thorne,${ }^{2}$ and A. R. Egan ${ }^{3}$ \\ ${ }^{1}$ Department of Primary Industries, DPI-Kyabram, Kyabram, Victoria 3620, Australia \\ ${ }^{2}$ Dexcel Ltd., Hamilton, New Zealand \\ ${ }^{3}$ The University of Melbourne, Institute of Land and Food Resources, \\ Parkville Victoria 3052, Australia
}

\begin{abstract}
Dairy cows grazing high-digestibility pastures exhibit pronounced diurnal variation in ruminal $\mathrm{pH}$, with $\mathrm{pH}$ being below values considered optimal for digestion. Using a dual-flow continuous culture system, the hypothesis that minimizing diurnal variation in $\mathrm{pH}$ would improve digestion of pasture when $\mathrm{pH}$ was low, but not at a higher $\mathrm{pH}$, was tested. Four treatments were imposed, with $\mathrm{pH}$ either allowed to exhibit normal diurnal variation around an average $\mathrm{pH}$ of 6.1 or 5.6 , or maintained at constant $\mathrm{pH}$. Digesta samples were collected during the last $3 \mathrm{~d}$ of each of four, 9-d experimental periods. A constant $\mathrm{pH}$ at 5.6 compared with a constant $\mathrm{pH}$ of 6.1 reduced the digestibility of organic matter $(\mathrm{OM})$, neutral detergent (NDF), and acid detergent fiber (ADF) by 7,14 , and $21 \%$, respectively. When $\mathrm{pH}$ was allowed to vary (averaging 5.6), digestion of $\mathrm{OM}$, $\mathrm{NDF}$, and $\mathrm{ADF}$ were reduced by 15,30 , and $36 \%$, respectively, compared with $\mathrm{pH}$ varying at 6.1 . There was little difference in digestion parameters when $\mathrm{pH}$ was either constant or varied with an average $\mathrm{pH}$ of 6.1. However, when average $\mathrm{pH}$ was 5.6, maintaining a constant $\mathrm{pH}$ significantly increased digestion of OM, NDF, and $\mathrm{ADF}$ by 5,25 , and $24 \%$ compared with a $\mathrm{pH}$ that exhibited normal diurnal variation. These in vitro results show that gains in digestibility and potential milk production can be made by minimizing diurnal variation in ruminal $\mathrm{pH}$, but only when ruminal $\mathrm{pH}$ is low (5.6). However, larger gains in productivity can be achieved by increasing average daily ruminal $\mathrm{pH}$ from 5.6 to 6.1 .
\end{abstract}

(Key words: ruminal $\mathrm{pH}$, pasture, diurnal variation, digestibility)

Abbreviation key: DOMD = organic matter digestibility of DM, C5.6 = constant $\mathrm{pH}$ of 5.6, C6.1 = constant $\mathrm{pH}$ of $6.1, \mathbf{M E}=$ metabolizable energy, V5.6 = normal

Received October 11, 2003.

Accepted January 19, 2004.

Corresponding author: W. J. Wales; e-mail: bill.wales@dpi. vic.gov.au. diurnal variation at an average $\mathrm{pH}$ of 5.6, V6.1 = normal diurnal variation at an average $\mathrm{pH}$ of 6.1 , respectively.

\section{INTRODUCTION}

Understanding the influence of ruminal $\mathrm{pH}$ on digestibility is important when devising feeding strategies. Recent studies suggest a different relationship exists between ruminal $\mathrm{pH}$ and digestion parameters when cows are fed fresh pasture compared with TMR. A study of 121 pasture-based diets explored relationships between ruminal fluid $\mathrm{pH}$ and measurements of rumen fermentation of pasture and its effect on animal production (Kolver and de Veth, 2002). Mean daily ruminal fluid $\mathrm{pH}$ varied from 5.6 to 6.7. Low ruminal $\mathrm{pH}$ was associated with a higher microbial $\mathrm{N}$ flow from the rumen, higher milk yield, and lower concentrations of milk fat. Milk yields were highest in the $\mathrm{pH}$ range 5.8 to 6.2. These $\mathrm{pH}$ levels are considered below optimal for digestion of TMR, but the in vivo and in vitro studies suggest a greater tolerance of low $\mathrm{pH}$ when low-starch pasture diets with high fiber fermentability are fed (de Veth and Kolver, 2001a; Kolver and de Veth, 2002). Although de Veth and Kolver (2001a) reported that digestion of pasture was optimized at $\mathrm{pH} 6.35$ in an in vitro continuous culture system, digestion and synthesis of microbial protein were largely insensitive to $\mathrm{pH}$ across a broad range of $\mathrm{pH}$ from 5.8 to 6.6.

In addition to having a low average daily ruminal $\mathrm{pH}$, grazing dairy cows offered highly digestible pasture often have pronounced diurnal variation in ruminal $\mathrm{pH}$, with $\mathrm{pH}$ ranging from 5.5 to 6.8 over a 24 -h period (Carruthers et al., 1997; Kolver and de Veth, 2002; Wales and Doyle, 2003). What is unclear is the extent to which diurnal variation vs. average daily $\mathrm{pH}$ affects ruminal digestion and microbial protein synthesis.

Variation in ruminal $\mathrm{pH}$ can be explained in part by the diurnal grazing pattern of the cow and periodicity of DMI and subsequent rumination (Wales and Doyle, 2003). Ruminal $\mathrm{pH}$ is the net effect of rates of production and absorption of acidic fermentation products and the addition of buffers to the rumen via saliva. Williams 
et al. (2001) reported that the average daily ruminal $\mathrm{pH}$ of grazing dairy cows was lower when DMI was high and was lower when Persian clover (Trifolium resupinatum L.) was consumed compared with perennial ryegrass (Lolium perenne L.). This research appears to represent the lowest average daily ruminal $\mathrm{pH}$ (5.6) reported for grazing dairy cows.

For cows consuming concentrate/forage diets, Hoover (1986) suggested that cyclic and short duration reductions in culture $\mathrm{pH}$ below 6.2 would cause a moderate, transient reduction in fiber digestion. However, further $\mathrm{pH}$ reductions in the range 5.0 to 5.5 for longer periods would cause severe reductions in OM and fiber digestion through reduced growth rates and numbers of cellulolytic organisms. This is supported by experiments of Stewart (1977), who showed that in vitro digestion of cellulose was completely inhibited when $\mathrm{pH}$ was 5.2.

Viable cellulolytic microbial populations remain present in the rumen as long as ruminal fluid $\mathrm{pH}$ is above the required $\mathrm{pH}$ threshold for sufficient periods during the day to permit microbial growth at rates equal to or greater than fiber passage rate (Weimer, 1998). However, this threshold is not well defined. De Veth and Kolver (2001b) maintained $\mathrm{pH}$ in continuous culture at a suboptimal level (5.4) for 4- to 12-h periods. Results suggested that the period of time that $\mathrm{pH}$ was below optimal ( $\mathrm{pH}$ 6.3) may be more critical for digestion than the relationship between mean daily $\mathrm{pH}$ and optimal $\mathrm{pH}$.

Reducing diurnal variation in ruminal $\mathrm{pH}$ may provide opportunities to improve digestion and, subsequently, milk production. A review of 35 experiments that have increased feeding frequency demonstrated average increases in milk fat concentrations of $7 \%$ and milk fat yield of 8\% (Gibson, 1984). Improvements in milk fat concentrations have only been reported for diets that included more than $60 \%$ concentrate (Sutton et al., 1985). Compared with these high-starch diets, the average ruminal $\mathrm{pH}$ of cows grazing good-quality pasture is approximately 6.15 (Kolver and de Veth, 2002). It might be expected that a more stabilized rumen environment would not improve milk fat concentrations on these diets. However, the impact of diurnal variation on digestibility is uncertain when very fermentable forages, such as clover or ryegrass, being rapidly growing, result in low average daily ruminal $\mathrm{pH}$ (5.6; Williams et al., 2001).

The current study tested two hypotheses using dualflow continuous culture fermenters with a diet of highly digestible perennial ryegrass pasture: 1) digestion of $\mathrm{OM}, \mathrm{NDF}$, and $\mathrm{ADF}$ will be lower when the average daily culture $\mathrm{pH}$ is maintained at a constant $\mathrm{pH}$ of 5.6 compared with 6.1 , and 2 ) diurnal variation in culture
Table 1. Metabolizable energy concentrations (MJ/kg of DM) and chemical composition of the perennial ryegrass diet (\% of DM).

\begin{tabular}{lc}
\hline Composition & \\
\hline $\mathrm{ME}^{1}$ & 12.3 \\
$\mathrm{OM}$ & 89.8 \\
$\mathrm{CP}^{2}$ & 19.0 \\
$\mathrm{NDF}$ & 43.2 \\
$\mathrm{ADF}$ & 23.1 \\
$\mathrm{NSC}$ & 16.3 \\
$\mathrm{Crude}$ fat & 4.00 \\
$\mathrm{Ca}$ & 0.48 \\
$\mathrm{Mg}$ & 0.19 \\
$\mathrm{P}$ & 0.39 \\
$\mathrm{Na}$ & 0.21 \\
$\mathrm{~K}$ & 3.12 \\
\hline
\end{tabular}

${ }^{1} \mathrm{ME}=$ Metabolizable energy $=$ organic matter digestibility of $\mathrm{DM}$ $\times 0.16$.

${ }^{2} \mathrm{CP}=\% \mathrm{~N} \times 6.25$.

${ }^{3} \mathrm{NSC}=$ Water-soluble carbohydrate and starch.

$\mathrm{pH}$ will reduce digestibility when average culture fluid $\mathrm{pH}$ is 5.6 , but not when culture $\mathrm{pH}$ is 6.1 .

\section{MATERIALS AND METHODS}

Four treatments were tested where highly digestible perennial ryegrass was fed to 4 fermenters twice daily during 49 -d periods according to a randomized complete block design. Culture $\mathrm{pH}$ was either allowed to exhibit normal diurnal variation around an average $\mathrm{pH}$ of 6.1 or 5.6 (V6.1 and V5.6, respectively), or maintained at a constant $\mathrm{pH}$ equivalent to the average $\mathrm{pH}$ of the variable treatments (C6.1 and C5.6). The rationale for selecting the treatments was to represent the diurnal patterns of ruminal $\mathrm{pH}$ observed in dairy cows grazing highly digestible pasture and to investigate opportunities to improve digestion by minimizing diurnal $\mathrm{pH}$ variation. The pasture fermented was of sufficient quality to result in a mean daily culture $\mathrm{pH}$ of 6.1 (V6.1). The $\mathrm{pH} 5.6$ treatments were chosen to reflect the lowest mean daily $\mathrm{pH}$ reported for a pasture diet (Williams et al., 2001).

Highly digestible, ryegrass-dominant herbage (composition described in Table 1) was freeze-dried and ground through a $1.6-\mathrm{mm}$ screen (Christy Laboratory Mill, Ipswich, UK) and formed into loose pellets (25 $\mathrm{mm}$ diameter $\times 15 \mathrm{~mm}$ long). Portions of these pellets were added to the fermenters in two equal meals per day at 12-h intervals. This feeding regimen was used to mimic the diurnal variation in intake and ruminal $\mathrm{pH}$ observed in grazing dairy cows that are offered two fresh allocations of pasture each day. Wales and Doyle (2003) reported that ruminal $\mathrm{pH}$ typically varied by \pm $0.5 \mathrm{pH}$ units from the average daily $\mathrm{pH}$ for cows grazing 


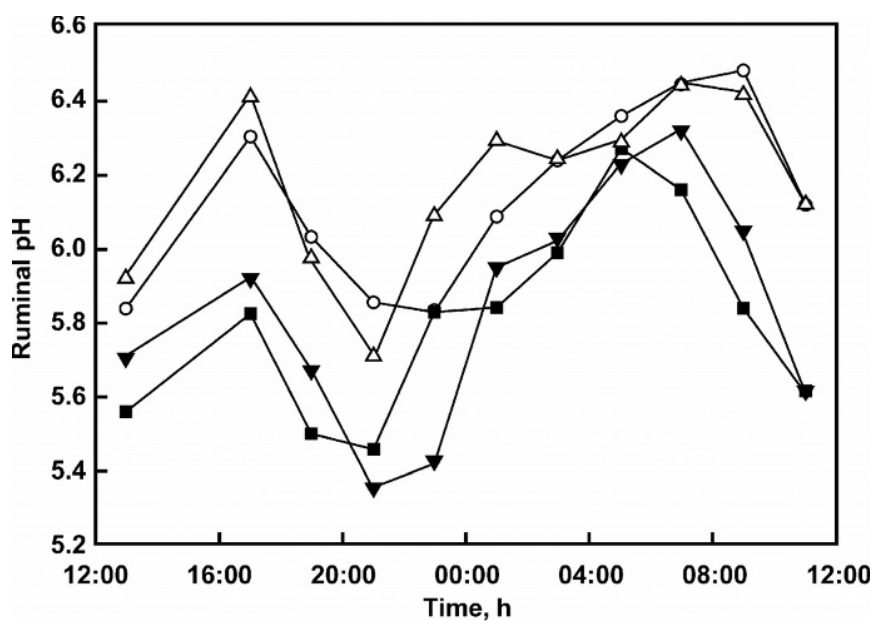

Figure 1. Diurnal variation in rumen fluid $\mathrm{pH}$ for pasture only $(\bigcirc)$, pasture plus $1.6 \mathrm{~kg}$ of DM straw $(\Delta)$, pasture plus $4.7 \mathrm{~kg}$ of DM grain ( $)$, or pasture plus $5.0 \mathrm{~kg}$ of DM grain and $1.7 \mathrm{~kg}$ of straw ( $\mathbf{\nabla})$ (Wales and Doyle, 2003).

clover offered at a low herbage allowance (Figure 1). The current in vitro study achieved a similar range in $\mathrm{pH}$ units $( \pm 0.5)$ and a similar 2-peak pattern in culture $\mathrm{pH}$ (Figure 2).

De Veth and Kolver (2001a) have described the operation of the in vitro dual-flow continuous culture system. At the start of each period ruminal inoculum was obtained from the same lactating, ruminally cannulated Holstein-Friesian cow grazing a highly digestible, perennial ryegrass-based pasture. Eight liters of ruminal fluid and approximately $200 \mathrm{~g}$ of digesta were collected

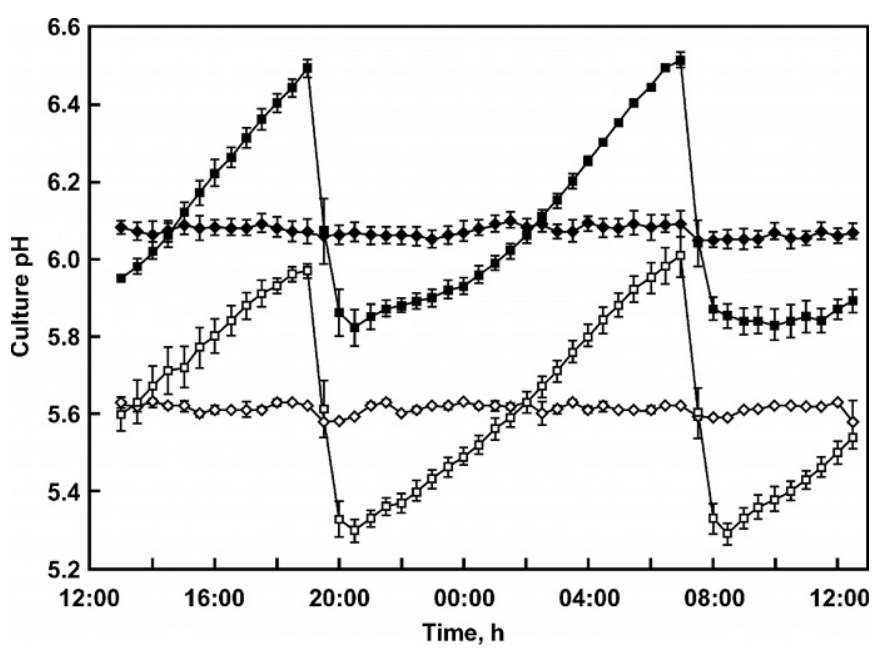

Figure 2. Average daily culture $\mathrm{pH}( \pm \mathrm{SE})$ in response to continuous culture $\mathrm{pH}$ maintained at a constant value of $6.1(\diamond)$ or $5.6(\diamond)$, or allowed to express normal diurnal variation around an average daily culture $\mathrm{pH}$ of $6.1(\square)$ or $5.6(\square)$. at $1230 \mathrm{~h}$ and transferred to the laboratory in prewarmed, insulated containers. Ruminal fluid was slowly mixed for $30 \mathrm{~s}$ in a Rotor bar blender $(4 \mathrm{~L}$ capacity; Rotor Ptd. Ltd., Neuheiten, Switzerland), and fermenters were inoculated within 25 min of collection. Approximately $5 \mathrm{~g}$ of fresh ruminal digesta was added to each fermenter to supply particle-associated bacteria.

Agitation was set at $160 \mathrm{rpm}$, and the temperature of the culture maintained at $39^{\circ} \mathrm{C}$. The culture was continuously infused with $\mathrm{N}_{2}$ to maintain anaerobiosis. The liquid dilution rate was maintained at $12 \% / \mathrm{h}$, and the solid dilution rate was held at $5 \% / \mathrm{h}$ (equivalent to a retention time of 8.3 and $20 \mathrm{~h}$, respectively) by the regulation of buffer input, acid and alkali input (for C6.1 and C5.6), and filtrate removal rates. The dilution rates were similar to those used in previous continuous culture studies (de Veth and Kolver, 2001a).

Culture $\mathrm{pH}$ was kept constant $( \pm 0.05 \mathrm{pH}$ unit) for $\mathrm{C} 6.1$ and $\mathrm{C} 5.6$ by automatic administration of $5 \mathrm{~N} \mathrm{HCl}$ and $5 \mathrm{~N} \mathrm{NaOH}$. Treatment $\mathrm{C} 6.1$ cows received $21 \pm 5.0$ $\mathrm{mL} \mathrm{HCl} / \mathrm{d}$ (mean $\pm \mathrm{sd}$ ) and $23 \pm 3.9 \mathrm{~mL} \mathrm{NaOH} / \mathrm{d}$ compared with $39 \pm 12.5 \mathrm{~mL} \mathrm{HCl} / \mathrm{d}$ of acid and $17 \pm 1.5 \mathrm{~mL}$ $\mathrm{NaOH} / \mathrm{d}$ for C5.6 cows. Cows in 3 of the treatments (C6.1, V6.1, and C5.6) received mineral buffer (Teather, 1990) and cows in the V5.6 group received mineral buffer acidified with $\mathrm{HCl}$ at concentrations equivalent to $22 \mathrm{~mL}$ of $5 \mathrm{~N} \mathrm{HCl} / \mathrm{d}$. The acidification of the buffer solution was designed to achieve an average culture $\mathrm{pH}$ that was equivalent to C5.6. It resulted in a $0.5 \mathrm{pH}$ decrease compared with V6.1 and maintained a variation $( \pm 0.5 \mathrm{pH}$ units) and diurnal pattern similar to those of V6.1 (Figure 2). Culture $\mathrm{pH}$ was automatically recorded every $30 \mathrm{~min}$ for the duration of the experiment.

Inputs of acid and alkali, temperature, filtration flow, and agitation were recorded immediately prior to each feeding. The solid and liquid effluent (simulating ruminal outflow to the small intestine) were weighed at 1300 $\mathrm{h}$ each day to determine dilution rates and discarded until the last $3 \mathrm{~d}$ of each period. On the last $3 \mathrm{~d}$ of effluent collection, a water bath maintained the effluent at $4^{\circ} \mathrm{C}$ to limit microbial fermentation in the effluent. During the $3 \mathrm{~d}$ of effluent collection, liquid and solid effluent portions were mixed each day and homogenized using a 4 -L blender, and a $600-\mathrm{mL}$ subsample was collected and stored at $4^{\circ} \mathrm{C}$. Two $25-\mathrm{mL}$ samples of effluent were also squeezed through 2 layers of cheesecloth, with 1 sample being acidified with $0.23 \mathrm{~mL}$ of $50 \% \mathrm{H}_{2} \mathrm{SO}_{4}$. These samples were stored at $-20^{\circ} \mathrm{C}$ and later analyzed for VFA and ammonia N concentrations. The $600-\mathrm{mL}$ subsamples were composited, using a blender, across the sampling days for each treatment. A subsample of the composite $(800-\mathrm{mL})$ was collected for determination 
Table 2. Digestibility of nutrients of perennial ryegrass in response to continuous culture $\mathrm{pH}$ maintained at a constant value of 6.1 (C6.1) or 5.6 (C5.6), or allowed to express normal diurnal variation around an average daily culture $\mathrm{pH}$ of 6.1 (V6.1) or 5.6 (V5.6).

\begin{tabular}{llllll}
\hline & \multicolumn{4}{c}{ Interactions $^{1}$} \\
\cline { 2 - 5 } Item & $\mathrm{C} 6.1$ & V6.1 & C5.6 & V5.6 & SED $^{2}$ \\
\hline True digestibility (\%) & & & & & \\
DM & $63.8^{\mathrm{a}}$ & $66.9^{\mathrm{a}}$ & $58.2^{\mathrm{b}}$ & $55.0^{\mathrm{c}}$ & 1.43 \\
OM & $66.6^{\mathrm{a}}$ & $69.1^{\mathrm{a}}$ & $61.9^{\mathrm{b}}$ & $59.0^{\mathrm{c}}$ & 1.21 \\
Apparent digestibility (\%) & & & & & \\
DM & $55.7^{\mathrm{a}}$ & $57.7^{\mathrm{a}}$ & $50.3^{\mathrm{b}}$ & $46.1^{\mathrm{c}}$ & 1.42 \\
OM & $58.8^{\mathrm{a}}$ & $60.5^{\mathrm{a}}$ & $54.5^{\mathrm{b}}$ & $50.6^{\mathrm{c}}$ & 1.18 \\
NSC & $83.7^{\mathrm{a}}$ & $84.4^{\mathrm{a}}$ & $83.6^{\mathrm{a}}$ & $81.7^{\mathrm{b}}$ & 0.96 \\
Fiber digestibility (\%) & & & & & \\
NDF & $67.6^{\mathrm{a}}$ & $65.6^{\mathrm{a}}$ & $57.9^{\mathrm{b}}$ & $46.2^{\mathrm{c}}$ & 3.18 \\
ADF & $75.0^{\mathrm{a}}$ & $74.7^{\mathrm{a}}$ & $59.1^{\mathrm{b}}$ & $47.7^{\mathrm{c}}$ & 3.72 \\
\hline
\end{tabular}

${ }^{1}$ Main effects are not presented as all interactions were significant at $P<0.05$. Within rows, different letters denote significant differences at $P<0.05$.

${ }^{2} \mathrm{SED}=$ Standard error of the difference.

of DM concentrations. The remaining effluent was freeze-dried and ground through a 1-mm screen.

On the last day of each period, microorganisms were harvested by mixing the contents of each fermenter in a 4-L Rotor blender at high speed for $30 \mathrm{~s}$. Digesta was strained through 2 layers of nylon cloth $(100 \mu \mathrm{m})$ and centrifuged at $1000 \times \mathrm{g}$ for $10 \mathrm{~min}$ to remove feed particles. Microorganisms were isolated from the supernatant by centrifuging 3 times at $20,000 \times g$ for $30 \mathrm{~min}$ (Sorvall RC-5C centrifuge, Dupont, Newton, CT). Isolated microbial material was prepared for analyses by freeze-drying and grinding through a 1-mm screen.

Concentrations of VFA were determined according to Playne (1985) by automated GLC (5890A, Hewlett Packard, Avondale, PA). Concentrations of ammonia$\mathrm{N}$ were determined by autoanalyzer (Hitachi 717, Mannheim, Germany) using an ammonia kit UV method. Microbial samples were analyzed for ash and $\mathrm{N}$ (AOAC, 1990). Purine concentrations (Zinn and Owens,
1986) of microbial and effluent samples were determined. The ratio of $\mathrm{N}$ :purine in effluent and microbial samples was used to calculate microbial $\mathrm{N}$ flow from the fermenter and true DM and OM digestibility (corrected for microbial DM and OM, respectively). Pasture and effluent were analyzed for ash, N, NDF, ADF (Van Soest et al., 1991), and NSC (Dubios et al., 1956). The soluble N, crude fat, and mineral concentrations of the diet were also determined (AOAC, 1990). The pasture was analyzed for OM digestibility of DM (DOMD) by near infrared reflectance spectroscopy (Ulyatt et al., 1995). Metabolizable energy (ME, MJ/kg DM) was calculated from DOMD, $(\mathrm{ME}, \mathrm{MJ} / \mathrm{kg}$ of $\mathrm{DM}=\mathrm{DOMD} \times$ 0.16 ; ARC, 1980). A sample of the mineral buffer solution was taken on each collection day and combined for $\mathrm{DM}$ and ash determination. True and apparent nutrient digestibilities (\%) were defined as intake minus effluent divided by intake, with the effluent corrected for buffer DM.

Data was analyzed by ANOVA according to a $2 \times 2$ factorial, with level of average daily $\mathrm{pH}$ (6.1 or 5.6) and pattern of diurnal $\mathrm{pH}$ (variable or constant) as main effects, employing a randomized complete block experimental design using Genstat (Oxford, UK). Data from only 3 periods contributed to the analysis of C5.6; as in period 4 , this treatment required approximately 3 times the acid to maintain $\mathrm{pH}$ as the same treatment in the other periods, and we suspected that fermentation had ceased some time prior to $5 \mathrm{~d}$ after inoculation. Main effects only are presented when interactions were not significant. Significance was determined at $P=0.05$.

\section{RESULTS}

There were significant interactions between level of average daily culture $\mathrm{pH}$ and pattern of diurnal culture $\mathrm{pH}$ for nutrient digestibility parameters (Table 2). The true digestibility of $\mathrm{OM}$ and $\mathrm{DM}$ were highest $(P<0.05)$ for the treatments with $\mathrm{pH} 6.1$ (C6.1 and V6.1), inter-

Table 3. Concentrations of total VFA, molar proportions of important individual acids and ratios of molar proportions of lipogenic:glucogenic VFA when culture $\mathrm{pH}$ averaged either $\mathrm{pH} 6.1$ or 5.6, or when the diurnal pattern of $\mathrm{pH}$ was maintained at a constant value or allowed to express normal diurnal variation.

\begin{tabular}{lcccccc}
\hline & \multicolumn{4}{c}{ Main effects } \\
\cline { 2 - 4 } & \multicolumn{2}{c}{$\mathrm{pH}$} & & \multicolumn{2}{c}{ Diurnal $\mathrm{pH}$} & \\
\cline { 2 - 3 } \cline { 5 - 6 } Item & 6.1 & 5.6 & & Constant & Variable & SED $^{1}$ \\
\hline Total VFA (mmol/L) & $66.7^{\mathrm{a}}$ & $49.9^{\mathrm{b}}$ & & $61.7^{\mathrm{a}}$ & $54.9^{\mathrm{b}}$ & 2.23 \\
Acetate (mmol/mol total VFA) & $572^{\mathrm{a}}$ & $495^{\mathrm{b}}$ & & 541 & 526 & 11.2 \\
Propionate (mmol/mol total VFA) & $218^{\mathrm{b}}$ & $249^{\mathrm{a}}$ & & 235 & 232 & 8.6 \\
$n$-Butyrate (mmol/mol total VFA) & $146^{\mathrm{b}}$ & $176^{\mathrm{a}}$ & & 158 & 164 & 12.3 \\
A/P & $2.64^{\mathrm{a}}$ & $2.00^{\mathrm{b}}$ & & 2.32 & 2.31 & 0.090 \\
\hline
\end{tabular}

${ }^{1} \mathrm{SED}=$ Standard error of the difference. Within rows for each main effect, different letters denote significant differences at $P=0.05$.

${ }^{2} \mathrm{~A} / \mathrm{P}=$ Molar proportions, where $\mathrm{A}$ is acetate and $\mathrm{P}$ is propionate. 
Table 4. Ammonia-N concentrations, true $\mathrm{CP}$ digestibility (CP digestibility adjusted for microbial $\mathrm{N}$ ), flows of nitrogen, and efficiency of microbial-N production when daily fluid $\mathrm{pH}$ averaged either $\mathrm{pH} 6.1$ or 5.6 or when the diurnal pattern of $\mathrm{pH}$ was constant or allowed to exhibit normal diurnal variation.

\begin{tabular}{|c|c|c|c|c|c|}
\hline \multirow[b]{3}{*}{ Item } & \multicolumn{4}{|c|}{ Main effects } & \multirow[b]{3}{*}{$\mathrm{SED}^{1}$} \\
\hline & \multicolumn{2}{|c|}{$\mathrm{PH}$} & \multicolumn{2}{|c|}{ Diurnal pattern } & \\
\hline & 6.1 & 5.6 & Constant & Variable & \\
\hline Ammonia-N, mg/100 mL & $15.5^{\mathrm{a}}$ & $13.5^{\mathrm{b}}$ & 14.5 & 14.4 & 0.73 \\
\hline True CP digestibility,\% & $76.6^{\mathrm{a}}$ & $58.3^{\mathrm{b}}$ & 68.4 & 66.4 & 2.62 \\
\hline \multicolumn{6}{|l|}{ Flows, g/d } \\
\hline Total N & $1.56^{\mathrm{b}}$ & $1.82^{\mathrm{a}}$ & $1.64^{\mathrm{b}}$ & $1.74^{\mathrm{a}}$ & 0.035 \\
\hline Ammonia $\mathrm{N}$ & $0.60^{\mathrm{a}}$ & $0.52^{\mathrm{b}}$ & 0.57 & 0.56 & 0.028 \\
\hline Dietary N & $0.43^{\mathrm{b}}$ & $0.76^{\mathrm{a}}$ & 0.58 & 0.62 & 0.048 \\
\hline Microbial N & 0.53 & 0.54 & $0.50^{\mathrm{b}}$ & $0.57^{\mathrm{a}}$ & 0.022 \\
\hline Nonammonia N & $0.96^{\mathrm{b}}$ & $1.30^{\mathrm{a}}$ & $1.07^{\mathrm{b}}$ & $1.19^{\mathrm{a}}$ & 0.050 \\
\hline \multicolumn{6}{|l|}{ Flows, $\%$ of nonammonia $\mathrm{N}$ flow } \\
\hline Dietary N & $44.5^{\mathrm{b}}$ & $58.6^{\mathrm{a}}$ & 52.4 & 50.7 & 2.99 \\
\hline Microbial N & $55.5^{\mathrm{a}}$ & $41.4^{\mathrm{b}}$ & 47.6 & 49.3 & 2.99 \\
\hline \multicolumn{6}{|l|}{ Microbial efficiency } \\
\hline $\mathrm{g}$ of $\mathrm{N} / \mathrm{kg}$ of DM truly digested & $13.4^{\mathrm{b}}$ & $15.9^{\mathrm{a}}$ & $13.6^{\mathrm{b}}$ & $15.7^{\mathrm{a}}$ & 0.69 \\
\hline $\mathrm{g}$ of $\mathrm{N} / \mathrm{kg}$ of $\mathrm{OM}$ truly digested & $13.3^{\mathrm{b}}$ & $15.3^{\mathrm{a}}$ & $13.2^{\mathrm{b}}$ & $15.4^{\mathrm{a}}$ & 0.65 \\
\hline
\end{tabular}

${ }^{1} \mathrm{SED}=$ Standard error of the difference. Within rows for each main effect, different letters denote significant differences at $P=0.05$.

mediate for C5.6, and lowest for the V5.6 treatment. Apparent digestibility of NSC was lowest $(P<0.05)$ on V5.6 treatment, and was higher and not different on the other three treatments. The digestibility of NDF and ADF was highest $(P<0.05)$ and not different for C6.1 and V6.1, intermediate for the C5.6, and lowest for V5.6.

There was a reduction $(P<0.001)$ in the concentrations of total VFA when the average daily culture $\mathrm{pH}$ was reduced from 6.1 to 5.6 (Table 3). A lower culture $\mathrm{pH}$ also altered the molar proportions of VFA. Acetate and n-butyrate were significantly reduced $(P<0.05)$ and propionate was significantly increased $(P<0.01)$ when culture $\mathrm{pH}$ decreased from 6.1 to 5.6. As a result, the ratios of the molar proportions of the lipogenic to glucogenic VFA, (expressed as acetate:propionate) were significantly reduced $(P<0.001)$ when culture $\mathrm{pH}$ was reduced from 6.1 to 5.6 .

Concentrations of total VFA in culture were higher $(P<0.01)$ when the pattern of diurnal $\mathrm{pH}$ was held constant compared with when it was allowed to vary (Table 3). However, the molar proportions of acetate, propionate, and n-butyrate, and the ratio of the molar proportions of lipogenic:glucogenic VFA were not influenced by the diurnal pattern of $\mathrm{pH}$.

The concentrations of ammonia $\mathrm{N}$ and the true digestibility of $\mathrm{CP}$ were significantly reduced $(P<0.05)$ when the average daily culture $\mathrm{pH}$ decreased from 6.1 to 5.6 (Table 4). The flow of total $\mathrm{N}$ increased when culture $\mathrm{pH}$ decreased $(P<0.001)$ from 6.1 to 5.6 . This increase in total $\mathrm{N}$ flow was partly due to an increase $(P<0.001)$ in the flow of nonammonia $\mathrm{N}$ but was partly offset by a small decrease $(P<0.05)$ in the flow of ammonia $\mathrm{N}$.
When $\mathrm{pH}$ was 6.1 , microbial protein synthesis was less $(P<0.01)$ efficient than at a culture $\mathrm{pH}$ of 5.6.

The concentrations of ammonia $\mathrm{N}$ and the true digestibility of $\mathrm{CP}$ were not influenced by the diurnal pattern of culture $\mathrm{pH}$ (Table 4). However, flow of total $\mathrm{N}$ was reduced $(P<0.05)$ when the diurnal pattern of culture $\mathrm{pH}$ was constant compared with variable diurnal pattern, with the differences partly attributed to a decrease $(P<0.01)$ in the flow of microbial N. Flows of dietary, ammonia and nonammonia $\mathrm{N}$ were not influenced by the pattern of diurnal culture $\mathrm{pH}$. Microbial production was less $(P<0.05)$ efficient when the diurnal pattern of culture $\mathrm{pH}$ was constant compared with when it was variable.

\section{DISCUSSION}

This experiment quantified the effect of diurnal variation in ruminal culture $\mathrm{pH}$ as being separate from the general effect of average daily $\mathrm{pH}$. Digestion parameters were not different when culture $\mathrm{pH}$ was either allowed to vary normally throughout the day about 6.1 in response to twice daily feeding or maintained at a constant $\mathrm{pH}$ of 6.1 . However, when average culture $\mathrm{pH}$ was 5.6, maintaining a constant $\mathrm{pH}$ significantly increased digestion of $\mathrm{OM}, \mathrm{NDF}$, and $\mathrm{ADF}$ compared with a culture exhibiting normal diurnal variation in $\mathrm{pH}$. Digestion at pH 5.6 (C5.6) was significantly lower than digestion at $\mathrm{pH} 6.1$ (C6.1), which is consistent with previous research (de Veth and Kolver, 2001a; Kolver and de Veth, 2002). 


\section{Effect of Ruminal pH on Digestibility when pH Is Held Constant}

The reduced true OM digestibility of pasture $(7 \%)$ when culture $\mathrm{pH}$ was kept constant at 5.6 compared with constant at $\mathrm{pH} 6.1$ supported our first hypothesis; however, the reduction in digestibility was less than the reduction observed with high-starch diets. With mixed diets over a similar range in $\mathrm{pH}$, digestion of $\mathrm{OM}$ was reduced by more than 19\% (Hoover et al., 1984; Shriver et al., 1986), and it is generally considered that a $\mathrm{pH}$ below 6.2 is suboptimal for microbial growth (Pitt et al., 1996). In the current experiment, the size of the reduction in $\mathrm{OM}$ digestibility was consistent with an analysis of datasets with grazing cows. Kolver and de Veth (2002) identified relationships between ruminal $\mathrm{pH}$ and measurements of ruminal fermentation and animal production variables from 121 diets based on fresh pastures from 23 experiments. Mean daily ruminal fluid varied from $\mathrm{pH} 5.6$ to 6.7, and they demonstrated that low ruminal $\mathrm{pH}$ was associated with a higher microbial $\mathrm{N}$ flow from the rumen, higher milk yields, and lower concentrations of milk fat. The highest milk yields occurred in the $\mathrm{pH}$ range of 5.8 to 6.2 , with only one data point below $\mathrm{pH} 5.8$. These results support the use of this in vitro system as a model of in vivo digestion and provide further evidence that the digestion of herbage is less compromised than mixed forageconcentrate diets within the $\mathrm{pH}$ range of 5.8 to 6.2. The critical $\mathrm{pH}$ for maintenance of acceptable digestibility appears to be about 5.8, as the current experiment showed reduced digestibility at 5.6.

\section{Effect of Ruminal pH on Digestibility when pH Is Allowed to Express Normal Diurnal Variation}

Dairy cows grazing pastures have pronounced diurnal ruminal fluid $\mathrm{pH}$ patterns (Wales and Doyle, 2003). Generally, this variation is observed as 2 rapid declines in $\mathrm{pH}$ coinciding with access to a fresh allocation of herbage following each milking. However, average daily $\mathrm{pH}$ from cows grazing pastures varies significantly with amount of pasture consumed and nutritive characteristics of the pasture (Williams et al., 2001). The variable diurnal $\mathrm{pH}$ treatments imposed in the current experiment mimicked those observed in dairy cows grazing highly digestible pasture and illustrated the potential improvement in digestibility if diurnal variation could be minimized.

Digestion coefficients of $\mathrm{OM}, \mathrm{NDF}$, and $\mathrm{ADF}$ were reduced by 15,30 , and $36 \%$, respectively, when average daily culture $\mathrm{pH}$ was allowed to vary throughout the day in response to twice-daily feeding at $\mathrm{pH} 5.6 \mathrm{vs}$. with 6.1 (V5.6 vs. V6.1). The lower $\mathrm{pH}$ is at the extreme reported for grazing dairy cows occurring when large amounts of highly digestible pasture are consumed. This suggests that digestibility of fiber fractions, in particular, may be considerably reduced in vivo. Approximately two-thirds of the $15 \%$ reduction in the digestion of $\mathrm{OM}$ was attributed to a reduction in the digestibility of NDF, and one-third was attributed to a reduced ADF digestibility. It appears that there was a proportional reduction in the digestibility of both the hemicellulose and $\mathrm{ADF}$ fractions.

\section{Impact of Reduced Digestibility on Milk Production}

Reductions in digestibility of the magnitude observed in our experiment would be expected to have a measurable impact on milk production. If a similar postruminal digestibility between treatments was assumed, a decrease in ruminal $\mathrm{pH}$ from 6.1 to 5.6 would reduce $\mathrm{OM}$ digestibility by 10 percentage units. This would represent a decrease in energy supply of approximately 2.0 $\mathrm{MJ}$ of $\mathrm{ME} / \mathrm{kg}$ of $\mathrm{DM}$ and equates to approximately 6.5 $\mathrm{kg}$ of milk for a grazing dairy cow consuming $18 \mathrm{~kg}$ of DM. If the diurnal variation in ruminal $\mathrm{pH}$ can be removed, additional energy equivalent to $2 \mathrm{~kg}$ of milk would be expected at a ruminal $\mathrm{pH}$ of 5.6 as a result of a 3 percentage unit increase in OM digestibility.

The larger, negative impact of a variable ruminal $\mathrm{pH}$ when $\mathrm{pH}$ was low (5.6) compared with a $\mathrm{pH}$ of 6.1 supported our second hypothesis. This suggests that feeding strategies, such as more frequent feeding that minimize diurnal variation in ruminal $\mathrm{pH}$, will give significant benefits when daily $\mathrm{pH}$ is low (5.6). In the review of Gibson (1984), feeding more frequently than twice daily increased milk fat concentrations by $7 \%$. However, within experiments, significant responses to increased frequency of feeding have only occurred when milk fat concentrations were originally depressed. There is little information on the impact of feeding frequency on milk fat concentrations for dairy cows grazing pasture. Dalley et al. (2001) reported no milk yield benefits to increasing the feeding frequency of pasture from once daily to 6 times per day. Although data on ruminal fluid $\mathrm{pH}$ were not reported, milk fat concentrations averaged $4 \%$ for Holstein-Friesian cows receiving a single daily allocation of pasture. These cows were clearly not milk fat depressed; therefore, benefits of frequent feeding were unlikely to be realized. Based on findings of the present experiment, only those cows consuming diets of highly digestible herbage resulting in low ruminal $\mathrm{pH}$ (e.g. 5.6), with pronounced diurnal variation, are likely to respond to more frequent feeding. Milk fat concentrations could be used to indicate whether a response to frequent feeding might be expected. 
As there were no differences between the digestion characteristics of the two treatments averaging $\mathrm{pH}$ 6.1, we can conclude that there is little advantage, in terms of improvements in digestion of $\mathrm{OM}$ or $\mathrm{NDF}$, in attempting to minimize diurnal variation of ruminal $\mathrm{pH}$ on most pasture diets. This conclusion is supported by in vitro research with TMR that showed no differences in digestion between a constant $\mathrm{pH} 6.4$ and one that fluctuated to $\mathrm{pH} 5.7$ for $4 \mathrm{~h}, 3$ times daily (Calsamiglia et al., 2002).

\section{Reduced pH Affects Fiber Digestibility}

The lower true OM digestibility as a result of a lower $\mathrm{pH}$ (5.6) when $\mathrm{pH}$ was constant was a direct result of a reduction in fiber digestibility. Approximately threefourths of the $7 \%$ reduction in $\mathrm{OM}$ digestibility was attributed to a reduction in NDF digestibility. Cellulolytic microorganisms are less tolerant of low $\mathrm{pH}$ than are amylolytic and saccharolytic microorganisms; therefore, their contribution to the microbial pool is decreased at low $\mathrm{pH}$, leading to reduced fiber digestion (Russell and Dombrowski, 1980). However, we are speculating that there was a shift toward strains of prominent fiber-digesting bacteria that tolerate a $\mathrm{pH}$ of less than 6.0 because there was only a relatively small reduction in OM digestibility and no changes in flow of bacterial $\mathrm{N}$. There is evidence that some fiber-digesting bacteria are not affected by prolonged periods of ruminal pH below 6.0. For example, Weimer et al., (1999) demonstrated that three important cellulolytic bacteria (Ruminococcus albus, Ruminococcus flavefacians, and Fibrobacter succinogenes) temporarily suspended growth during the period immediately after feeding when ruminal $\mathrm{pH}$ was relatively acidic, and resumed growth on recovery of $\mathrm{pH}$.

The observation in this experiment that water-soluble carbohydrate and starch digestion was not affected by $\mathrm{pH}$ is supported by other research (Hoover et al., 1984; Shriver et al., 1986; de Veth and Kolver, 2001a). These studies showed that NSC was highly digestible over a wide range in $\mathrm{pH}(\mathrm{pH} 4.5$ to 7.5$)$ and concluded that microorganisms participating in digestion are largely insensitive to $\mathrm{pH}$ change.

The $25 \%$ decrease in total VFA concentrations as $\mathrm{pH}$ decreased from 6.1 to 5.6 is in agreement with other continuous culture studies (Hoover et al., 1984; Shriver et al., 1986). However, our results are greater than the $13 \%$ reduction reported by de Veth and Kolver (2001a) over the same range. The decrease in VFA concentrations at low $\mathrm{pH}$ was associated with reduced microbial growth (expressed as flow of microbial $\mathrm{N}$ as a proportion of nonammonia $\mathrm{N}$ ) and the reduced digestibility of the fiber fractions. The large reduction in the molar propor- tion of acetate and smaller, though significant, increases in propionate and butyrate at low $\mathrm{pH}$ (5.6), are in accordance with previous studies (Hoover et al., 1984; de Veth and Kolver, 2001a).

Total VFA concentrations in the current study was reduced by $11 \%$ when diurnal patterns of $\mathrm{pH}$ were applied, a result in broad agreement with other studies of diurnal variation in ruminal $\mathrm{pH}$ (Hoover et al., 1984; Shriver et al., 1986; Russell, 1998; de Veth and Kolver, 2001b). The lack of an effect of diurnal variation on the $M$ proportions of individual VFA indicates that the changes in these proportions are due solely to changes in $\mathrm{pH}$ throughout the day.

In vitro studies that control culture $\mathrm{pH}$ at or above 6.1 are useful for examining the effects on digestion observed in grazing cows that generally express pronounced diurnal variation in $\mathrm{pH}$. However, using these systems to study low $\mathrm{pH}$ (5.6) may not adequately reflect digestion that occurs when $\mathrm{pH}$ varies during the day.

\section{CONCLUSIONS}

This experiment has quantified the separate effects of diurnal variation of culture $\mathrm{pH}$, and the effect of average daily culture $\mathrm{pH}$ on the digestion of ryegrass in continuous culture. Digestion parameters were similar when culture $\mathrm{pH}$ was either maintained at a constant $\mathrm{pH}$ 6.1, or when $\mathrm{pH}$ varied about $\mathrm{pH} 6.1$ throughout the day. However, when culture $\mathrm{pH}$ was 5.6 , maintaining a constant $\mathrm{pH}$ significantly increased digestion of $\mathrm{OM}$, $\mathrm{NDF}$, and ADF compared with a culture in which $\mathrm{pH}$ expressed normal diurnal variation. Feed digestibility and milk production may be improved with feeding strategies that minimize diurnal variation at low ruminal $\mathrm{pH}$ (5.6). However, larger improvements in productivity will occur by using feeding strategies that result in a higher $\mathrm{pH}$ (6.1).

\section{REFERENCES}

AOAC. 1990. Official Methods of Analysis. Assoc. Offic. Anal. Chem., Washington, DC.

ARC. 1980. The Nutrient Requirements of Ruminant Livestock. Commonwealth Agricultural Bureaux, Wallingford, UK.

Calsamigli, S., A. Ferret, and M. Devant. 2002. Effects of pH and $\mathrm{pH}$ fluctuations on microbial fermentation and nutrient flow from a dual-flow continuous culture system. J. Dairy Sci. 85:574-579.

Carruthers, V. R., P. G. Neil, and D. E. Dalley. 1997. Effect of altering the non-structural:structural carbohydrate ratio in a pasture diet on milk production and ruminal metabolites in cows in early and late lactation. Anim. Sci. 64:393-402.

Dalley, D. E., J. R. Roche, P. J. Moate, and C. Grainger. 2001. More frequent allocation of herbage does not improve the milk production of dairy cows in early lactation. Aust. J. Exp. Agric. 41:593-599.

de Veth, M. J., and E. S. Kolver. 2001a. Digestion of ryegrass pasture in response to change in $\mathrm{pH}$ in continuous culture. J. Dairy Sci. 84:1449-1457. 
de Veth, M. J., and E. S. Kolver. 2001b. Diurnal variation in $\mathrm{pH}$ reduces digestion and synthesis of microbial protein when pasture is fermented in continuous culture. J. Dairy Sci. 84:2066-2072.

Dubios, M., K. A. Gilles, J. K. Hamilton, P. A. Rebers, and F. Smith. 1956. Colorimetric method for determination of sugar and related substances. Anal. Chem. 28:250-256.

Gibson, J. P. 1984. The effects of frequency of feeding on milk production of dairy cattle: An analysis of published results. Anim. Prod. 38:181-189.

Hoover, W. H. 1986. Chemical factors involved in ruminal fiber digestion. J. Dairy Sci. 69:2755-2766.

Hoover, W. H., C. R. Kincaid, G. A. Varga, W. V. Thayne, and L. L. Junkins, Jr. 1984. Effects of solids and liquid flows on fermentation in continuous cultures. IV. $\mathrm{pH}$ and dilution rate. J. Anim. Sci. 58:692-699.

Kolver, E. S., and M. J. de Veth. 2002. Prediction of ruminal pH from pasture-based diets. J. Dairy Sci. 85:1255-1266.

Pitt, R. E., J. S. Van Kessel, D. G. Fox, A. N. Pell, M. C. Barry, and P. J. Van Soest. 1996. Prediction of ruminal volatile fatty acids and $\mathrm{pH}$ within the net carbohydrate and protein system. J. Anim. Sci. 74:226-244.

Playne, M. J. 1985. Determination of ethanol, volatile fatty acids, lactic and succinic acids in fermentation liquids by gas chromatography. J. Sci. Food Agric. 36:638-644.

Russell, J. B. 1998. The importance of $\mathrm{pH}$ in the regulation of ruminal acetate to propionate ratio and methane production in vitro. J. Dairy Sci. 81:3222-3230.

Russell, J. B., and D. B. Dombrowski. 1980. Effect of $\mathrm{pH}$ on the efficiency of growth by pure cultures of rumen bacteria in continuous culture. Appl. Environ. Microbiol. 39:604-610.
Shriver, B. J., W. H. Hoover, J. P. Sargent, R. J. Crawford, Jr., and W. V. Thayne. 1986. Fermentation of a high concentrate diet as affected by ruminal $\mathrm{pH}$ and digesta flow. J. Dairy Sci. 69:413-419.

Stewart, C. S. 1977. Factors affecting the cellulolytic activity of rumen contents. Appl. Environ. Microbiol. 33:497-502.

Sutton, J. D., W. H. Broster, D. J. Napper, and J. W. Siviter. 1985. Feeding frequency for lactating cows: effects on digestion, milk production and energy utilisation. Br. J. Nutr. 53:117-130.

Teather, R. M. 1990. General protocols for operation and monitoring of the artificial rumen. Pages 14-16 in Continuous Culture Fermentors: Frustration or Fermentation. NE ADSA-ASAS Regional Mtg., Chazy, NY.

Ulyatt, M. J., J. Lee, and D. Corson. 1995. Assessing feed quality. Ruakura Farmers Conference. 59-62.

Van Soest, P. J., J. B. Robertson, and B. A. Lewis. 1991. Methods for dietary fiber, neutral detergent fiber, and nonstarch polysaccharides in relation to animal nutrition. J. Dairy Sci. 74:35833597.

Wales, W. J., and P. T. Doyle. 2003. The effect of grain and straw supplementation on marginal milk production responses and rumen fermentation of cows grazing highly digestible subterranean clover herbage. Aust. J. Exp. Agric. 43:467-474.

Weimer, P. J. 1998. Manipulating ruminal fermentation: a microbial ecological perspective. J. Anim. Sci. 76:3114-3122.

Weimer, P. J., G. C. Waghorn, C. D. Odt, and D. R. Mertens. 1999. Effect of diet on populations of three species of ruminal cellulolytic bacteria in lactating dairy cows. J. Dairy Sci. 82:122-134.

Williams, Y. J., G. P. Walker, W. J. Wales, and P. T. Doyle. 2001. Effect of pasture type and intake on the rumen $\mathrm{pH}$ of grazing cows in spring. Aust. J. Dairy Tech. 56:163.

Zinn, R. A., and F. N. Owens. 1986. A rapid procedure for purine measurement and its use for estimating net ruminal protein synthesis. Can. J. Anim. Sci. 66:157-166. 